María Izquierdo \& Frida Kahlo 
THIS PAGE INTENTIONALLY LEFT BLANK 

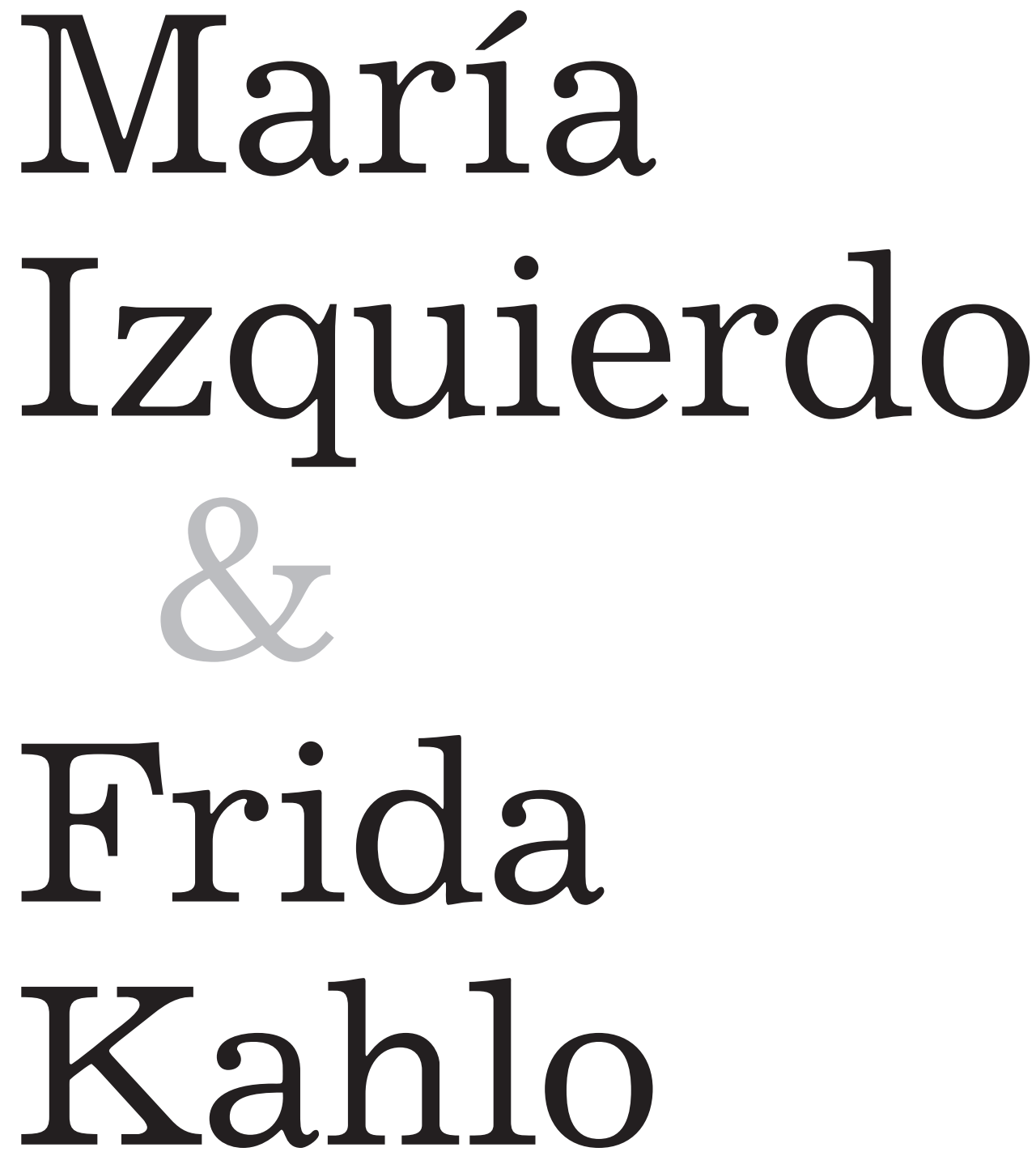

CHALLENGING VISIONS IN MODERN MEXICAN ART

Nancy Deffebach 


\section{To my friends}

\section{Kim Grant, Daniel Nelson, Susan Webster, Florencia Bazzano, and Ana Garduño}

This book is a part of the Latin American and Caribbean Arts and Culture publication initiative, funded by a grant from the Andrew W. Mellon Foundation.

\section{CATIN AMERICAN \\ ARTS AND CULTURE}

Copyright $\odot 2015$ by the University of Texas Press All rights reserved

Printed in the United States of America

First edition, 2015

Requests for permission to reproduce material from this work should be sent to:

Permissions

University of Texas Press

P.O. Box 7819

Austin, TX 78713-7819

http://utpress.utexas.edu/index.php/rp-form

(2) The paper used in this book meets the minimum requirements of ANSI/NISO Z39.48-I992 (RI997) (Permanence of Paper).

Library of Congress Cataloging-in-Publication Data

Deffebach, Nancy, author.

María Izquierdo and Frida Kahlo : challenging visions in modern Mexican art /

Nancy Deffebach. - First edition.

pages $\mathrm{cm}$ - (Latin American and Caribbean Arts and Culture publication initiative (Andrew W. Mellon Foundation))

Includes bibliographical references and index.

ISBN 978-0-292-77242-7 (cloth : alk. paper) — ISBN 978-I-4773-0049-7 (library e-book)

— ISBN 978-I-4773-0050-3 (non-library e-book)

I. Izquierdo, María, 1902-I955-Criticism and interpretation. 2. Kahlo, Frida-

Criticism and interpretation. 3. Women artists-Mexico. 4. Feminism and art. I. Title. ND259.I97D46 2015

$759.972-\mathrm{dc} 23 \quad 2014046327$

doi:10.7560/772427 